Jurnal Tropicrops

Vol 4 No. 2, Agustus 2021: 78-87

p-ISSN: 2615-7020, e-ISSN: 2615-7012

\title{
PENGARUH PEMBERIAN DOSIS PUPUK ORGANIK GRANUL DAN PUPUK PHONSKA PLUS TERHADAP PERTUMBUHAN TANAMAN TEBU (Saccharum officinarum L.) DENGAN METODE BAGAL SATU MATA TUNAS

\author{
THE EFFECT OF DOSING GRANUL ORGANIK FERTILIZER AND \\ PHONSKA PLUS FERTILIZER ON THE GROWTH OF SUGARCANE \\ (Saccharum officinarum L.) USING THE ONE-EYED MULE METHOD
}

\author{
Diana Fitriyah Rahayu ${ }^{1 *}$, Setyo Budi ${ }^{2}$, Wiharyanti NurLailiyah ${ }^{3}$ \\ $1^{*}, 2,3$ Program studi Agroteknologi Fakultas Pertanian Universitas Muhammadiyah Gresik
}

Jin. Sumatra No. 101 GKB, Gresik - Jawa Timur

diana.rahayu3101@gmail.com¹, setyobudi@umg.ac.id², wiharyanti@umg.ac.id ${ }^{3}$

\section{ABSTRAK}

Tanaman tebu (Saccharum officinarum L.) merupakan bahan baku pembuatan gula. Produksi tanaman tebu mengalami penurunan yang diakibatkan oleh pemupukan yang tidak seimbang dan metode penanaman bibit tebu. Penelitian ini bertujuan untuk meningkatkan produksi tanaman tebu. Hal ini dapat ditempuh melalui pemberian pupuk organik granul dan pupuk phonska plus yang berimbang dengan menggunakan metode bagal satu mata tunas. Penelitian ini dilaksanakan di kebun percobaan Agroteknologi di Desa Klangonan, Gresik pada bulan Mei - Juli 2020. Metode yang digunakan dalam penelitian adalah Rancangan Acak Kelompok (RAK) dengan dua faktor. Faktor pertama Pupuk Organik Granul (G) dengan dua taraf yaitu Gi dan G2 dan Pupuk Phonska Plus (P) dengan tiga taraf yaitu Po, Pi, P2 dan diulang tiga kali sehingga terdapat 18 kombinasi perlakuan. Analisis data menggunakan Anova dengan uji F 5\%. Jika terdapat beda nyata maka dilanjutkan dengan uji Beda Nyata Terkecil (BNT) 5\%. Hasil penelitian menunjukkan pada perlakuan pemberian pupuk organik granul terdapat beda nyata tertinggi dibandingkan perlakuan pemberian pupuk phonska plus pada semua umur pengamatan $(45,59,73$, dan $87 \mathrm{HST})$. Pada pemberian dosis pupuk organik granul $1.500 \mathrm{~kg} / \mathrm{ha}$ dapat meningkatkan tinggi batang dan diameter batang. Pada pemberian pupuk phonska plus pada dosis $200 \mathrm{~kg} / \mathrm{ha}$ dan $400 \mathrm{~kg} / \mathrm{ha}$ tidak terdapat perbedaan nyata pada semua variabel pengamatan. Terdapat interaksi perlakuan pemberian pupuk organik granul dan pupuk phonska plus pada pengamatan tinggi batang dan diameter batang terhadap pertumbuhan tanaman tebu. Perlakuan paling efektif yaitu G2P1 (pemberian pupuk organik granul $1.500 \mathrm{~kg} / \mathrm{ha}+$ pupuk phonska plus $200 \mathrm{~kg} / \mathrm{ha}$ ) dapat meningkatkan produksi tanaman tebu.

Kata Kunci : Tanaman Tebu, Pupuk Organik Granul, Pupuk Phonska Plus

\section{ABSTRACT}

Sugarcane (Saccharum officinarum L.) is a raw material for sugar. Sugarcane production has decreased due to unbalanced fertilization and sugarcane methods. This study aims to increase sugarcane production. This can be achieved through the provision of granule organic fertilizer using the one-eyed mule method. This research was conducted at the Agrotechnology Experimental Garden in Klangonan village, Gresik in May - July 2020. The experiment used a two-factor Randomized Block Design (RBD). The first factor was organic fertilizer granul (G) and Phonska Plus fertilizer with three levels, namely Po, Pi, and P2. Each was repeated three times so that there were 18 tratment combinations. Data analysis using ANOVA with F test $5 \mathrm{~b} \%$. 
If there is a significant difference, then proceed with the Least Significant Difference (LSD) test of 5\%. The results showed that in the treastment of granule organic fertilizer there was the highest significant difference compared to the treatment of Phonska plus fertilizer application at all ages $(45,59,73$, and $87 \mathrm{HST})$. The dose of organic fertilizer granule $1.500 \mathrm{~kg} / \mathrm{ha}$ can increase stem height and stem diameter. In the application of phonska plus fertilizer at a dose of 200 $\mathrm{kg} / \mathrm{ha}$ and $400 \mathrm{~kg} / \mathrm{ha}$ there was no significant difference in all the observed variables. There is an interaction between the treatment of organic fertilizer granul and phonska plus fertilizer on the observation of stem height and stem diameter on the growth of sugarcane. The most effective treatment, namely G2P1 (giving organic granule fertilizer $1.500 \mathrm{~kg} / \mathrm{ha}+$ Phonska Plus fertilizer $200 \mathrm{~kg} / \mathrm{ha}$ ) can increase sugarcane production.

Keywords : Sugarcane, Organic Granule Fertilizer, Phonska Plus Fertilizer

\section{PENDAHULUAN}

Tanaman tebu merupakan tanaman yang dijadikan sebagai bahan baku pembuatan gula (Sukmadajaja dan Mulyana, 2011). Kebutuhan gula dalam negeri semakin meningkat namun, hal ini berbeda dengan produksi tanaman tebu yang menurun. Pada tahun 2014, luas lahan tebu seluas 476,735 ha dengan produksi gula nasional sebesar 26.332,424 ton (Badan Pusat Statistik, 2015). Salah satu faktor menurunannya produksi antara lain kualitas benih, kebutuhan pupuk, kebutuhan air, dan kondisi tanah. Menurut Prasetyo dan Suriadikarta (2006) kualitas tanah yang tanah yang menurun disebabkan oleh penggunaan pupuk organik dan pupuk anorganik yang tidak berimbang. Petani banyak yang menggunakan pupuk anorganik untuk memenuhi kebutuhan hara tanaman tanpa menyeimbangkan dengan pemberian pupuk organik. Salah satu upaya yang dilakukan yaitu dengan memberikan dosis pupuk organik granul dan pupuk phonska plus yang tepat.

Penggunaan pupuk organik dalam budidaya tanaman dapat menambah unsur hara dalam tanah, memperbaiki struktur tanah (Khairullah, (2010) dalam Ayu, Wiwik Indrawati, Albertus Sudirman (2017)). Menurut Ayu, dkk (2017) penggunaan pupuk organik dengan dosis $1.000 \mathrm{~kg} / \mathrm{ha}$ berpengaruh pada jumlah tebu dan jumlah ruas tebu. Selain itu, penambahan pupuk organik dapat juga dilakukan dengan melakukan penambahan pupuk anorganik.

Menurut Nasution, Titiek dan Husni (2013) perlakuan pupuk majemuk NPK dosis $400 \mathrm{~kg} / \mathrm{ha}$ dan pupuk ZA $800 \mathrm{~kg} / \mathrm{ha}$ berpengaruh nyata terhadap diameter batang tanaman. Selain itu, menurut Jaili, M. A B., dan Purwono (2016) pemberian pupuk phonska dengan dosis $500 \mathrm{~kg} / \mathrm{ha}$ pada tanaman tebu dapat meningkatkan produktivitas tanaman tebu lahan kering. Dosis pemberian pupuk yang tidak tepat akan menghambat pertumbuhan dan perkembangan tanaman tebu.

Rendahnya produksi gula di Indonesia ini disebabkan oleh penyiapan bibit tebu yang kurang tepat. Hal ini sesuai dengan pernyataan Putri A. D., Sudiarso, dan T. Islami (2013) penyebab rendahnya produksi gula dalam negeri salah satunya penyimpanan bibit yang berkualitas. Metode bagal satu mata tunas merupakan metode penanaman tebu dengan menggunakan bibit tebu yang memiliki satu mata tunas yang terletak pada tengah antar dua ruas (Oktami, Wantia, Wiwik Indrawati dan Abdul Aziz, 
2016). Oleh karena itu diperlukannya inovasi agar produksi tanaman tebu dapat meningkat dengan pemberian dosis pupuk organik granul dan pupuk phonska plus yang tepat. Sehingga dapat meningkatkan produksi tanaman tebu.

\section{BAHAN DAN METODE}

\section{Tempat dan Waktu}

Penelitian dilaksanakan di Kebun Percobaan Agroteknologi Fakultas Pertaian di Desa Klangonan, Kecamatan Kebomas, Kabupaten Gresik. Penelitian dilaksanakan pada bulan Mei - Juli 2020.

\section{Alat dan Bahan}

Bahan yang digunakan adalah tanaman tebu, pupuk organik granul dan pupuk phonska plus. Alat yang digunakan ialah cangkul, sabit, tali rafia, gembor, thermometer max-min, $\mathrm{pH}$ tanah, dan timbangan.

\section{Metode Penelitian \\ Rancangan Percobaan}

Penelitian menggunakan Rancangan Acak Kelompok (RAK) Faktorial, yang terdiri dari dua faktor yaitu Gi (Dosis pupuk organik granul $1.000 \mathrm{~kg} / \mathrm{ha}$ ), G2 (Dosis pupuk organik $1.500 \mathrm{~kg} / \mathrm{ha}$ ). Faktor kedua yaitu Po (Tanpa pemberian pupuk phonska plus), Pi (Dosis pupuk phonska plus 200 $\mathrm{kg} / \mathrm{ha}$ ), P2 (Dosis pupuk phonska plus 400 $\mathrm{kg} / \mathrm{ha}$ ). Terdapat enam perlakuan dan tiga ulangan, sehingga diperoleh 18 satuan percobaan.

\section{Variabel Pertumbuhan}

\section{HASIL DAN PEMBAHASAN}

\section{Panjang Tanaman}

\section{Tabel 1. Rerata Panjang Tanaman (cm) Tanaman Tebu}

\begin{tabular}{|c|c|c|c|c|}
\hline \multirow{2}{*}{ Perlakuan } & \multicolumn{4}{|c|}{ Umur Pengamatan Hari Setelah Tanam (HST) } \\
\hline & 45 & 59 & 73 & 87 \\
\hline \multicolumn{5}{|c|}{. } \\
\hline Interaksi Pupuk Organik & Granul dan Pupuk Phonska Plus & & & \\
\hline G1P0 & 54.96 & $76.00 \mathbf{a}$ & $111.27 \mathbf{a b}$ & 131.71 \\
\hline G1P1 & 49.42 & $71.67 \mathbf{a}$ & $105.42 \mathbf{a}$ & 131.58 \\
\hline G1P2 & 56.08 & $81.54 \mathbf{a}$ & $112.96 \mathbf{a b}$ & 135.71 \\
\hline G2P0 & 68.04 & $97.92 \mathbf{b}$ & 128.33 be & 146.00 \\
\hline G2P1 & 69.88 & $96.04 \mathbf{b}$ & $136.79 \mathbf{c}$ & 150.88 \\
\hline $\mathrm{G} 2 \mathrm{P} 2$ & 53.83 & $75.46 \mathbf{a}$ & $100.33 \mathbf{a}$ & 129.00 \\
\hline BNT 0,05 & tn & 13.41 & 21.54 & tn \\
\hline \multicolumn{5}{|l|}{ Pupuk Organik Granul } \\
\hline Gl & $53.49 \mathbf{a}$ & $76.40 \mathbf{a}$ & 109.88 & 133.00 \\
\hline $\mathrm{G} 2$ & $63.92 \mathbf{b}$ & 89.81 b & 121.82 & 141.96 \\
\hline BNT 0,05 & 8.98 & 7.74 & tn & tn \\
\hline \multicolumn{5}{|l|}{ Pupuk Phonska Plus } \\
\hline $\mathrm{P} 0$ & 61.50 & 86.96 & 119.80 & 138.8542 \\
\hline PI & 59.65 & 83.85 & 121.10 & 141.2292 \\
\hline $\mathrm{P} 2$ & 54.96 & 78.50 & 106.65 & 132.3542 \\
\hline
\end{tabular}

Keterangan : Nilai pada kolom yang diikuti huruf berbeda menunjukkan berbeda nyata berdasarkan uji BNT $5 \%$, tn : tidak terdapat perbedaan nyata, Gi : pupuk organik granul $1.000 \mathrm{~kg} / \mathrm{ha}, \mathrm{G} 2$ : pupuk organik granul $1.500 \mathrm{~kg} / \mathrm{ha}$, Po: tanpa pemberian pupuk phonska plus , Pi : pupuk phonska plus 200 $\mathrm{kg} / \mathrm{ha}, \mathrm{P} 2$ : pupuk phonska plus $400 \mathrm{~kg} / \mathrm{ha}$

Hasil analisis BNT 5\% pada tabel 1. Menunjukkan terdapat interaksi nayata pada panjang tanaman pada kombinasi perlakuan pemberian pupuk organik granul dan pupuk 
phonska plus pada umur 59 dan 73 HST. Beda nyata tertinggi pada pengamatan 59 HST menunjukkan terdapat pada perlakuan G2 Po (pupuk organik granul $1.500 \mathrm{~kg} / \mathrm{ha}+$ tanpa pemberian pupuk phonska plus) dan beda nyata terendah pada perlakuan G1P1 (pupuk organik granul $1.000 \mathrm{~kg} / \mathrm{ha}+$ pupuk phonska plus $200 \mathrm{~kg} / \mathrm{ha}$ ). Beda nyata tertinggi pada umur 73 HST terdapat pada perlakuan G2P1 (pupuk organik granul 1.500 $\mathrm{kg} / \mathrm{ha}+$ pupuk phonska plus $200 \mathrm{~kg} / \mathrm{ha}$ ) dan beda nyata terendah pada perlakuan G2P2 (pupuk organik granul $1.500 \mathrm{~kg} / \mathrm{ha}+$ pupuk phonska plus $400 \mathrm{~kg} / \mathrm{ha}$ ). Namun, tidak terdapat perbedaan nyata pada umur 45 dan 87 HST.

Pelakuan pemberian pupuk organik granul menunjukkan perbedaan nyata pada umur 45 dan 59 HST namun, tidak terdapat perbedaan nyata pada umur 73 dan 87 HST. Beda nyata tertinggi pada umur 45 HST terdapat pada perlakuan G2 (pupuk organik granul $1.500 \mathrm{~kg} / \mathrm{ha}$ ) dan beda nyata terendah terdapat pada perlakuan Gi (pupuk organik granul $1.000 \mathrm{~kg} / \mathrm{ha}$ ). Beda nyata tertinggi pada umur 59 HST terdapat pada perlakuan G2 (pupuk organik granul $1.500 \mathrm{~kg} / \mathrm{ha}$ ) dan beda nyata terendah terdapat pada perlakuan Gi (pupuk organki granul $1.000 \mathrm{~kg} / \mathrm{ha}$ ). Pemberian pupuk phonska plus menunjukkan tidak terdapat perbedaan nyata pada semua variabel pengamatan dan semua umur pengamatan.

\section{Tinggi Batang}

Tabel 2. Rerata Tinggi Batang (cm) Tanaman Tebu

\begin{tabular}{|c|c|c|c|c|}
\hline Periakuan & \multicolumn{4}{|c|}{ Umur Pengamatan Hari Setelah Tanam (HSI) } \\
\hline \multicolumn{5}{|c|}{ Interaksi Pupuk Organik Granul dan Pupuk Phonska Plus } \\
\hline G1P0 & 7.17 & 12.40 & $16.75 \mathbf{a b}$ & $20.13 \mathbf{a}$ \\
\hline G1P1 & 7.54 & 11.96 & $15.83 \mathbf{a b}$ & $20.67 \mathbf{a}$ \\
\hline G1P2 & 8.04 & 11.88 & $17.42 \mathbf{a b}$ & $23.25 \mathbf{a b}$ \\
\hline $\begin{array}{l}\text { G2P0 } \\
\text { G2P1 }\end{array}$ & $\begin{array}{c}10.17 \\
9.83\end{array}$ & $\begin{array}{l}16.17 \\
15.04\end{array}$ & $\begin{array}{c}19.79 \mathbf{b c} \\
22.29 \mathbf{c}\end{array}$ & $\begin{array}{l}24.92 \mathbf{b} \\
25.88 \mathbf{b}\end{array}$ \\
\hline $\mathrm{G} 2 \mathrm{P} 2$ & 7.63 & 11.38 & $15.00 \mathbf{a}$ & $20.46 \mathbf{a}$ \\
\hline BNT 0,05 & tn & tn & 4.44 & 4.16 \\
\hline \multicolumn{5}{|c|}{ Pupuk Organik Granul } \\
\hline $\mathrm{Gl}$ & $7.58 \mathbf{a}$ & $12.08 \mathbf{a}$ & 16.67 & 21.35 \\
\hline $\mathrm{G} 2$ & $9.21 \mathbf{b}$ & $14.19 \mathbf{b}$ & 19.03 & 23.75 \\
\hline BNT 0,05 & 1.51 & 1.48 & tn & tn \\
\hline \multicolumn{3}{|c|}{ Pupuk Phonska Plus } & 18.27 & 22.52 \\
\hline $\mathrm{Pl}$ & 8.69 & $13.50 \mathbf{b}$ & 19.06 & 23.27 \\
\hline $\mathrm{P} 2$ & 7.83 & $11.63 \mathbf{a}$ & 16.21 & 21.85 \\
\hline BNT 0,05 & tn & 1.81 & tn & tn \\
\hline
\end{tabular}

Keterangan : Nilai pada kolom yang diikuti huruf berbeda menunjukkan berbeda nyata berdasarkan uji BNT 5\%, tn : tidak terdapat perbedaan nyata. Gi : pupuk organik granul $1.000 \mathrm{~kg} / \mathrm{ha}$. G? : pupuk organik granul $1.500 \mathrm{~kg} / \mathrm{ha}$. Po: tanpa pemberian pupuk phonska plus . Pi : pupuk phonska plus 200 $\mathrm{kg} / \mathrm{ha}, \mathrm{P} 2$ : pupuk phonska plus $400 \mathrm{~kg} / \mathrm{ha}$

Hasil analisis sidik ragam BNT 5\% pada tabel 2 menunjukkan terdapat interaksi nyata pada variabel pengamatan tinggi batang pada umur 73 dan 87 HST. Namun, tidak terdapat perbedaan nyata pada umur pengamatn 45 dan 59 HST. Beda nyata tertinggi pada umur 73 HST terdapat pada perlakuan G2P1 (pupuk organik granul 1.500 $\mathrm{kg} / \mathrm{ha}+$ pupuk phonska plus $200 \mathrm{~kg} / \mathrm{ha}$ ). Beda nyata terendah terdapat pada perlakuan G2P2 (pupuk organik granul $1.500 \mathrm{~kg} / \mathrm{ha}+$ pupuk phonska plus $400 \mathrm{~kg} / \mathrm{ha}$ ). Pada umur 
pengamatan 87 HST beda nyata tertinggi terdapat pada perlakuan G2P1 (pupuk organik granul $1.500 \mathrm{~kg} / \mathrm{ha}+$ pupuk phonska plus $200 \mathrm{~kg} / \mathrm{ha}$ ) dan beda nyata terendah terdapat pada perlakuan G1P0 (pupuk organik granul $1.000 \mathrm{~kg} / \mathrm{ha}+$ tanpa pemberian pupuk phonska plus).

Perlakuan pemberian pupuk organik granul menunjukkan perbedaan nyata pada umur 45 dan 59 HST. Namun, tidak terdapat perbedaan nyata pada umur 73 dan 87 HST. Beda nyata tertinggi pada umur 45 HST terdapat pada perlakuan G2 (pupuk organik granul $1.500 \mathrm{~kg} / \mathrm{ha}$ ) dan beda nyata terendah terdapat pada perlakuan Gi (pupuk organik granul $1.000 \mathrm{~kg} / \mathrm{ha}$ ). Pada umur pengamatan

\section{Diameter Batang}

Berdasarkan hasil analisis BNT 5\% pada tabel 3 menunjukkan tidak terdapat perbedaan nyata kombinasi pemberian pupuk organik granul dan pupuk phonska plus pada umur pengamatn 45 dan 59 HST. Namun, pada umur pengamatan 73 dan 87 HST. Beda nyata tertinggi pada umur 73 HST terdapat pada perlakuan G2P1 (pemberian pupuk organik granul 1.500 $\mathrm{kg} / \mathrm{ha}+$ pupuk phonska plus $200 \mathrm{~kg} / \mathrm{ha}$ ) dan beda nyata terendah terdapat pada perlakuan G1P1 (pemberian pupuk organik granul $1.000 \mathrm{~kg} / \mathrm{ha}+$ pupuk phonska plus 200 $\mathrm{kg} / \mathrm{ha}$ ). Pada umur 87 HST terdapat beda nyata tertinggi pada perlakuan G2P1 (pupuk (pupuk organik granul $1.500 \mathrm{~kg} / \mathrm{ha}$ ) dan beda nyata terendah terdapat pada perlakuan Gi (pupuk organik granul $1.000 \mathrm{~kg} / \mathrm{ha}$ ).

Pada umur 79 HST teradapat perbedaan nyata tertinggi pada perlakuan G2 (pupuk organik granuul $1.500 \mathrm{~kg} / \mathrm{ha}$ ). Beda 59 HST terdapat beda nyata tertinggi pada perlakuan G2 (pupuk organik granul 1.500 $\mathrm{kg} / \mathrm{ha}$ ) dan bedanyata terendah terdapat pada perlakuan Gi (pupuk organik granul 1.000 $\mathrm{kg} / \mathrm{ha}$ ).

Perlakuan pemberian pupuk phonska plus menunjukkan tidak terdapat perbedaan nyata pada umur pengamatan 45, 73 dan 87 HST. Namun, pada umur 59 HST terdapat beda nyata tertinggi pada perlakuan Po (tanpa pemberian pupuk phonska plus) dan beda nyata terendah terdapat pada perlakuan P2 (pemberian pupuk phonska plus 400 $\mathrm{kg} / \mathrm{ha}$ ).organik granul $1.500 \mathrm{~kg} / \mathrm{ha}+$ pupuk phonska plus $200 \mathrm{~kg} / \mathrm{ha}$ ) dan beda nyata terendahterdapat pada perlakuan G1P1 (pemberianpupuk organik granul $1.000 \mathrm{~kg} / \mathrm{ha}$ + pupuk phonska plus $200 \mathrm{~kg} / \mathrm{ha}$ ).

Perlakuan pemberian pupuk organik granul menunjukkan perbedaan nyata pada semua umur pengamatan 45, 59, 73 dan 87 HST. Beda nyata tertinggi pada umur 45 HST terdapat pada perlakuan G2 (pupuk organik granul $1.500 \mathrm{~kg} / \mathrm{ha}$ ) dan beda nyata terendah terdapat pada perlakuan $\mathrm{Gi}$ (pemberian pupuk organik granul 1.000 $\mathrm{kg} / \mathrm{ha}$ ). Pada umur pengamatan 59 HST beda nyata tertinggi terdapat pada perlakuan G2 nyata terendah terdapat pada perlakuan $\mathrm{Gi}$ (pupuk organik granul $1.000 \mathrm{~kg} / \mathrm{ha}$ ). perlakuan pemberian jenis pupuk phonska plus menunjukkan tidak terdapat perbedaan nyata pada umur pengamatan 45, 59, 73 dan 87 HST. 
Tabel 3. Rerata Diameter Batang (cm) Tanaman Tebu

\begin{tabular}{|c|c|c|c|c|}
\hline \multirow{2}{*}{ Perlakuan } & \multicolumn{4}{|c|}{ Umur Pengamatan Hari Setelah Tanam (HST) } \\
\hline & 45 & 59 & 73 & 87 \\
\hline \multicolumn{5}{|c|}{ 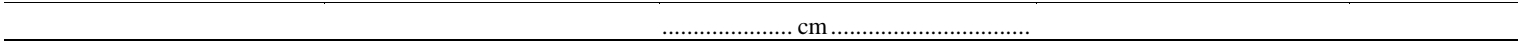 } \\
\hline \multicolumn{5}{|c|}{ Interaksi Pupuk Organik Granul dan Pupuk Phonska Plus } \\
\hline G1P0 & 0.21 & 0.38 & $0.58 \mathbf{a}$ & $0.79 \mathbf{a b}$ \\
\hline G1P1 & 0.18 & 0.40 & $0.48 \mathbf{a}$ & $0.74 \mathbf{a}$ \\
\hline G1P2 & 0.21 & 0.37 & $0.67 \mathbf{a b}$ & 0.96 be \\
\hline G2P0 & 0.30 & 0.60 & $0.83 \mathbf{b c}$ & $1.08 \mathrm{c}$ \\
\hline $\mathrm{G} 2 \mathrm{P} 1$ & 0.22 & 0.58 & $0.93 \mathbf{c}$ & $1.14 \mathrm{c}$ \\
\hline G2P2 & 0.23 & 0.43 & $0.59 \mathbf{a}$ & $0.87 \mathbf{a b}$ \\
\hline BNT 0,05 & tn & tn & 0.23 & 0.18 \\
\hline \multicolumn{5}{|c|}{ Pupuk Organik Granul } \\
\hline GI & $0.20 \mathbf{a}$ & $0.38 \mathbf{a}$ & $0.58 \mathbf{a}$ & $0.83 \mathbf{a}$ \\
\hline G2 & $0.25 \mathbf{b}$ & $0.53 \mathbf{b}$ & $0.78 \mathbf{b}$ & $1.03 \mathbf{b}$ \\
\hline BNT 0,05 & 0.04 & 0.13 & 0.13 & 0.10 \\
\hline \multicolumn{4}{|c|}{ Pupuk Phonska Plus } & 0.94 \\
\hline PI & 0.20 & 0.49 & 0.71 & 0.94 \\
\hline $\mathrm{P} 2$ & 0.22 & 0.40 & 0.63 & 0.91 \\
\hline BNT 0,05 & tn & tn & tn & tn \\
\hline
\end{tabular}

Keterangan : Nilai pada kolom yang diikuti huruf berbeda menunjukkan berbeda nyata berdasarkan uji BNT 5\%, tn : tidak terdapat perbedaan nyata, Gi : pupuk organik granul $1.000 \mathrm{~kg} / \mathrm{ha}, \mathrm{G} 2$ : pupuk organik granul $1.500 \mathrm{~kg} / \mathrm{ha}$. Po : tanpa pemberian pupuk phonska plus, $\mathrm{Pi}$ : pupuk phonska plus 200 $\mathrm{kg} / \mathrm{ha}, \mathrm{P} 2$ : pupuk phonska plus $400 \mathrm{~kg} / \mathrm{ha}$.

\section{Panjang Ruas}

\section{Tabel 4. Rerata Panjang Ruas (cm) Tanaman Tebu}

\begin{tabular}{|c|c|c|c|c|c|}
\hline \multirow{2}{*}{ Perlakuan } & \multicolumn{5}{|c|}{ Umur Pengamatan Hari Setelah Tanam (HST) } \\
\hline & 45 & 59 & 73 & \multicolumn{2}{|c|}{87} \\
\hline \multicolumn{6}{|c|}{ Interaksi Pupuk Organik Granul dan Pupuk Phonska PEis } \\
\hline G1P0 & & $2.54 \mathbf{a b}$ & 4.00 & 3.54 & 3.71 \\
\hline G1P1 & & $2.46 \mathbf{a}$ & 3.67 & 3.33 & 3.71 \\
\hline G1P2 & & $3.29 \mathbf{a b}$ & 3.50 & 3.63 & 4.08 \\
\hline G2P0 & & $3.46 \mathbf{b}$ & 4.04 & 3.83 & 3.96 \\
\hline G2P1 & & $3.29 \mathbf{a b}$ & 3.96 & 3.79 & 4.29 \\
\hline G2P2 & & $2.38 \mathbf{a}$ & 3.13 & 3.46 & 3.54 \\
\hline BNT 0,05 & & 0.96 & tn & tn & tn \\
\hline \multicolumn{2}{|c|}{ Pupuk Organik Granul } & 2.76 & 3.72 & 3.50 & 3.83 \\
\hline $\mathrm{G} 2$ & & 3.04 & 3.71 & 3.69 & 3.93 \\
\hline BNT 0,05 & & tn & tn & tn & tn \\
\hline $\begin{array}{l}\text { Pupuk Phonska } \\
\text { P0 }\end{array}$ & & 3.00 & $4.02 \mathrm{~b}$ & 3.69 & 3.83 \\
\hline PI & & 2.88 & $3.81 \mathrm{ab}$ & 3.56 & 4.00 \\
\hline P2 & & 2.83 & $3.31 \mathrm{a}$ & 3.54 & 3.81 \\
\hline BNT 0,05 & & tn & 0.52 & tn & tn \\
\hline
\end{tabular}

Keterangan : Nilai pada kolom yang diikuti huruf berbeda menunjukkan berbeda nyata berdasarkan uji BNT 5\%. tn : tidak terdapat perbedaan nyata. Gi : pupuk organik granul $1.000 \mathrm{~kg} / \mathrm{ha}$. G2 : pupuk organik granul $1.500 \mathrm{~kg} / \mathrm{ha}$, Pc: tanpa pemberian pupuk phonska plus , $\mathrm{Pi}$ : pupuk phonska plus 200 $\mathrm{kg} / \mathrm{ha}$. P2: pupuk phonska plus $400 \mathrm{~kg} / \mathrm{ha}$. nyata pada pengamatan panjang ruas pada

Berdasarkan hasil analisis BNT 5\% pada tabel 4 menunjukan terdapat interaksi kombinasi perlakuan pemberian pupuk organik granul dan pupuk phonska plus pada umur pengamatan $45 \mathrm{HST}$. Beda nyata 
tertinggi pada umur pengamatan 45 HST terdapat pada perlakuan G2P0 (pemberian pupuk organik granul $1.500 \mathrm{~kg} / \mathrm{ha}+$ tanpa pemberian pupuk phonska plus). Beda nyata terendah terdapat pada perlakuan G2P2 (pemberian pupuk organik granul 1.500 $\mathrm{kg} / \mathrm{ha}+$ pupuk phonska plus $400 \mathrm{~kg} / \mathrm{ha}$ ). Namun, pada umur pengamatan 59, 73, dan 87 HST tidak terdapat perbedaan nyata terhadap pengamatan panjang ruas.

Perlakuan pemberian pupuk organik granul menunjukan tidak terdapat perbedaan

\section{PEMBAHASAN}

Pengaruh Pemberian Pupuk Organik Granul Terhadap Pertumuhan Tanaman Tebu

Hasil analisis sidik ragam atau ANOVA 5\% menunjukkan bahwa perlakuan pemberian pupuk organik granul berpengaruh nyata pada pengamatan tinggi batang dan diameter batang pada umur 87 HST. Hal ini dikarenakan pemberian pupuk organik granul diserap secara lambat oleh tanaman.

Secara umum pupuk organik mengalami proses dekomposisi sebelum menjadi unsur hara yang akan diserap oleh tanaman (Budi, Setyo, dan Sasmita Sari, 2015). Setiap tanaman menyerap unsur hara berbeda-beda tergantung pada kemampuan tanaman. Pada pengamatan umur 45 dan 59 HST tidak terdapat perbedaan nyata, karena pada saat pemberian pupuk organik granul tanaman tidak bisa menyerap unsur hara secara langsung. Hal ini sesuai dengan hasil penelitian Cahyani, et all. (2016) bahwa unsur hara organik yang diberikan pada tanaman masih dalam bentuk ion atau kation, sehingga akar tanaman menyerap unsur hara dengan proses yang lambat.

Pemberian pupuk organik granul juga berpengaruh terhadap diameter batang tanaman tebu. Hal ini dikarenakan pupuk organik granul mengandung unsur hara Zn yang berfungsi sebagai katalisator pada tanaman (Budi, dan Sasmita. 2015). Namun, nyata pada semua umur pengamatan 45,59 ,
73, dan 89 HST pada pengamatan panjang ruas. Pada perlakuan pemberian jenis pupuk phonska plus menunjukan tidak terdapat perbedaan nyata pada pengamatan umur 45, 73, dan 87 HST pada pengamatan jumlah ruas. Beda nyata tertinggi pada umur pengamatan 59 HST terdapat pada perlakuan Po (tanpa pemberian pupuk phonska plus). Beda nyata terendah terdapat pada perlakuan P2 (pemberian pupuk phonska plus $400 \mathrm{~kg} / \mathrm{ha}$ ).

menurut Ayu, dkk. (2017) pemberian pupuk organik granul dengan dosis $1.000 \mathrm{~kg} / \mathrm{ha}$ berpengaruh pada jumlah anakan dan jumlah ruas tebu.

Pada hasil penelitian menunjukkan bahwa jumlah anakan dan jumlah ruas tidak berbeda nyata pada semua umur pengamatan. Hal ini diduga pemberian pupuk organik granul mengacu pada pertumbuhan diameter batang, sehingga tidak berpengaruh pada jumlah anakan dan jumlah ruas pada tanaman tebu. Pada musim kemarau tanah akan mengalami kekeringan yang menyebabkan tanaman kekurangan air dalam membantu proses pertumbuhannya. Pengaruh Pemberian Pupuk Phonska Plus Terhadap Pertumbuhan Tanaman Tebu

Hasil analisis sidik ragam atau ANOVA 5\% menunjukkan bahwa perlakuan pemberian pupuk phonska plus terhadap pertumbuhan tanaman tebu tidak berbeda nyata pada semua variabel pengamatan pada semua umur pengamatan. Hal ini diduga karena pupuk phonska plus memiliki kandungan unsur hara $\mathrm{N}, \mathrm{P}, \mathrm{K}, \mathrm{S}$ dan tambahan unsur hara yaitu $\mathrm{Zn}$.

Fase vegetatif tanaman tebu membutuhkan unsur hara $\mathrm{N}, \mathrm{P}, \mathrm{K}$ dan $\mathrm{S}$ dalam jumlah banyak pada masa vegetative tanaman tebu. Penambahan unsur hara $\mathrm{Zn}$ tidak berpengaruh nyata pada masa vegetative tanaman tebu. Hal ini sesuai dengan hasil penelitian Supriyadi, Nunik Eka Diana, dan Djumali (2017) aplikasi 
pupuk majemuk dalam bentuk granul maupun briket dengan dosis $700 \mathrm{~kg} / \mathrm{ha}$ (134 $\mathrm{kg} \mathrm{N}, 72 \mathrm{~kg} \mathrm{P} 2 \mathrm{O} 5,72 \mathrm{~kg}$ K2O) yang ditambah dengan pupuk Ammonium sulfat (ZA) dosis $300 \mathrm{~kg} / \mathrm{ha}$ dapat meningkatkan rendemen gula, sehingga dapat meningkatkan produksi tanaman tebu.

Menurut Sutedjo (2010) kurang lengkapnya unsur hara makro dan mikro, dapat menghambat petumbuhan, perkembangan dan produktifitas tanaman. Pemberian pupuk majemuk NPK dosis 400 $\mathrm{kg} / \mathrm{ha}$ dan pupuk ZA $800 \mathrm{~kg} / \mathrm{ha}$ dapat meningkatkan diameter batang tanaman tebu (Nasution, dkk. 2013).

Menurut

Purwanti

(2008)

peningkatan dosis pupuk majemuk dapat meningkatkan tinggi tanaman, diameter batang, luas daun, dan kadar klorofil daun. Namun, hasil penelitian tidak berpengaruh nyata pada jumlah anakan. Hal ini sesuai dengan penelitian Purwanti (2008) pemberian pupuk majemuk NPK dengan dosis $200 \mathrm{~kg} / \mathrm{ha}$ dapat berpengaruh nyata pada umur 6 bulan terhadap tinggi tanaman tebu. Hasil penelitian pada semua umur pengamatan tidak berbeda nyata terdahap semua variabel pengamatan.

\section{Interaksi Pupuk Organik granul dan pupuk phonska plus terhadap pertumbuhan tanaman tebu}

Ketersediaan unsur hara dalam tanah yang terbatas dapat terpenuhi dengan melakukan pemupukan (Purwanti, 2008). Oleh karena itu, perlu penambahan pupuk phonska plus supaya penyerapan unsur hara pada tanaman dapat tercukupi. Pemberian pupuk organik dan phonska plus merupakan perlakuan yang sesuai untuk meningkatkan produksi tanaman tebu. Perlakuan pemberian pupuk organik granul dan pupuk phonska plus terdapat perbedaan nyata pada variabel pengamatan tinggi batang dan diameter batang. Interaksi pemberian pupuk organik granul dan pupuk phonska plus pada perlakuan G2P1 (pupuk organik granul 1.500 $\mathrm{kg} / \mathrm{ha}+$ pupuk phonska plus $200 \mathrm{~kg} / \mathrm{ha}$ ). Hal ini sesuai dengan penelitian Rosdianingsih, Dini (2013) penggunaan pupuk organik dan pupuk anorganik yang seimbang dapat meningkatkan produksi tanaman tebu.

Pemberian pupuk organik dan pupuk anorganik secara langsung dapat meingkatkan unsur hara dalam tanah dan kesuburan tanah meningkat. Sehingga mikroba dalam tanah dapat mengikat unsur hara makro dan mikro oleh tanaman. Menurut Kriswantoro, H., Safriyani, E., dan Bahri, S. (2016) unsur hara yang diserap oleh akar akan ditranslokasikan pada tajuk tanaman untuk proses metabolisme tanaman yang digunakan dalam mendukung pertumbuhan dan produksi tanaman. Unsur hara dalam tanah yang dibutuhkan tanaman dalam masa vegetatif ialah unsur hara Nitrogen, Fosfor, Kalium dan Sulfur. Menurut Sutedjo (2010) unsur hara nitrogen sangat diperlukan dalam pembentukan bagian tanaman seperti batang dan daun, sehingga dosis nitrogen yang tinggi pada batas tertentu dapat meningkatkan hasil tanaman.

Menurut Adnan, I.S., Utoyo, B., dan Kusumastuti, A. (2015) pemberain pupuk npk dan organik mampu meningkatkan diameter batang. Hal ini diduga karena kondisi pertumbuhan tanaman yang cepat sehingga kombinasi perlakuan tersebut dapat meningkatkan pertumbuhan vegetatif tanaman tebu. Batang tanaman merupakan tempat akumulasi pertumbuhan tanaman khususnya tanaman muda. Unsur hara yang cukup dapat mendorong laju fotosintesis dalam menghasilkan fotosintat sehingga membantu dalam proses pembentukan batang tanaman.

Nitrogen dapat diserap tanaman melalui proses aliran massa (transpirasi). Secara fisiologi nitrogen memilki peranan yaitu reduksi metabolik nitrat dan asimilasi ammonia. Nitrogen dapat diserap tanaman 
dalam bentuk ion nitrat dan ammonium. Nitrat yang diserap oleh akar menuju ke atas bagian tanaman akibat proses transpirasi ke bagian daun. Asimilasi nitrat pada tanaman terjadi pada bagian daun, akar dan batang tanaman (Budi dan Sasmita, 2015).

Phospor dapat diserap oleh tanaman melalui proses difusi. Tanaman dapat menyerap unsur hara phosphor dalam bentuk ortofosfat primer, $\mathrm{H} 2 \mathrm{PO} 4$ ', $\mathrm{HPO}^{4}$ Penyerapan kedua ion dipengaruhi oleh kondisi $\mathrm{pH}$ dalam tanah. Phosphor berperan dalam merangsang partumbuhan dan perkembangan akar, sebagai bahan dasar (ATP dan ADP), membantu proses perbungaan dan pembuahan, membantu pemasakan biji dan buah, serta membantu asimilasi dan respirasi (Marsono dan Sigit, 2002).

Kalium diserap akar melalui proses intersepsi akar. Proses intersepsi akar merupakan proses perpanjangan akar yang memperpendek jarak dengan unsur hara, sehingga akar dapat menyerap unsur hara dengan optimal (Aziz, dkk, 2017). Tanaman dapat menyerap kalium dalam bentuk $\mathrm{K}+$ dengan cara pertukaran kation. Kalium berfungsi sebagai metabolisme karbohidrat, yakni pembentukan, pemecahan, dan translokasi pati, metabolisme nitrogen dan sintesis protein, mengaktifkan berbagai enzim, mempercepat pertumbuhan jaringan meristematik dan lainnya (Budi dan Sasmita, 2015).

\section{KESIMPULAN}

1. Pemberian pupuk organik granul dosis $\quad 1.500 \quad \mathrm{~kg} / \mathrm{ha}$ dapat meningkatkan tinggi batang dan diameter batang. Tinggi batang pada umur 59 HST menunjukkan rerata tertinggi $14,19 \mathrm{~cm}$ dan pada umur 87 HST menunjukkan rerata diameter batang tertinggi $1,03 \mathrm{~cm}$.

2. Pemberian pupuk phonska plus dosis $200 \mathrm{~kg} / \mathrm{ha}$ dan $400 \mathrm{~kg} / \mathrm{ha}$ tidak terdapat perbedaan nyata terhadap variabel pengamatan panjang tanaman, tinggi batang, jumlah anakan, jumlah daun, diameter batang, jumlah ruas, panjang ruas dan luas daun pada umur pengamatan 45, 59, 73, $87 \mathrm{HST}$.

3. Terdapat interaksi antara pemberian pupuk organik dan pupuk phonska plus terhadap tinggi batang pada umur pengamatan 87 HST menunjukkan rerata tertinggi 25,88 $\mathrm{cm}$, sedangkan pada diameter batang tanaman tebu umur 87 HST menunjukkan rerata tertinggi 1,14 cm pada perlakuan G2P1 (Pemberian pupuk organik granul $1.500 \mathrm{~kg} / \mathrm{ha}+$ pupuk phonska plus $200 \mathrm{~kg} / \mathrm{ha}$ ).

\section{DAFTAR PUSTAKA}

Adnan, I.S., Utoyo, B., dan Kusumastuti, A. (2015) Pengaruh Pupuk Npk Dan Pupuk Organik Terhadap Pertumbuhan Bibit Kelapa Sawit (Elaeis guineensis Jacq.) Di Main Nursery. Jurnal AIP 3:2 Hal: 69-81.

Ayu, Eka R. A., Wiwik Indrawati, dan Albertus Sudirman. 2017. Pengaruh Pupuk Organik Padat dan Varietas pada Produktivitas Tebu (Saccharum officinarum L.). Jurnal Agro Industri Perkebunan.

Badan Pusat Statistik. 2015. Produksi Tebu Menurut Provinsi di Indonesia.

Budi, Setyo dan Sasmita Sari. 2015. Ilmu dan Implementasi Kesuburan Tanah. UMMPres. Malang. Hal. 45-54.

Cahyani, Suci, Albertus Sudirman, dan Abdul Azis. 2016. Respons Pertumbuhan Vegetatif Tanaman Tebu (Saccharum officinarum L.) Ratoosn 1 terhadap Pemberian Kombinasi Pupuk Organik dan Pupuk Anorganik. Jurnal Agro Industri Perkebunan 4(2): 69-78. 
Diana, Nunik Eka, Sujak, dan Djumali.2017. Efektivitas Aplikasi Pupuk Majemuk NPK Terhadap Produktivoitas dan Pendapatan Petani Tebu. Buletin Tanaman Tembakau, Serat dan Minyak Industri 9 (2).

Hawalid, Heniyati dan Ekki Herri Widodo. 2018. Pengaruh Jenis Dan Takaran Pupuk Organik Terhadap Pertumbuhan Bibit Tanaman Tebu (Saccharum officinarum L.J Di Pollybag. Skripsi Fakultas Pertanian Universitas Muhammadiyah Palembang. XIII - 2 : 99 - 103.

Jaili, Mohd Azree Bin dan Purwono. 2016. Pengurangan Dosis Pupuk Anorganik dengan Pemberian Kompos Blotong pada Budi Daya TanamanTebu (Saccharum officinarum L.) Lahan Kering. Jurnal Bul.Agrohorti 4(1): 113121.

Kriswantoro, H., Safriyani, E., dan Bahri, S. 2016. Pengaruh Pupuk Organik Dan Pupuk Npk Pada Tanaman Jagung Manis (Zea mays saccharata Sturt). Jurnal Klorofil 11:1-6.

Marsono dan Sigit P., 2002. Pupuk Akar, Jenis dan Aplikasi. Penebar Swadaya. Jakarta.

Nasution, K. H., Islami, T., Sebayang, H. T. 2013. Pengaruh Dosis Pupuk Anorganik Dan Pengendalian Gulma Pada Pertumbuhan Vegetatif Tanaman Tebu (Saccharum Officinarum L.J Varietas Ps. 881. Jumal Produksi Tanaman. 1 (4): 299 - 307.

Oktami, Wantia, Wiwik Indrawati, dan Abdul Aziz, 2016. Perbandingan Pertumbuhan Jumlah Mata Tunas Bibit Bagal Tebu (Saccharum officinarum L.) GMP2 dan GMP3. Jurnal Agro Industri Perkebunan. 4 (1)21-30.

Putri A. D., Sudiarso, dan T. Islami. 2013. Pengaruh Komposisi Media Tanam pada Teknik Bud Chip Tiga Varietas Tebu (Saccharum officinarum L.J. Jurusan Budidaya Pertanian Fakultas
Pertanian. Universitas Brawijaya. Malang.

Purwanti, E. 2008. Pengaruh Dosis Pupuk Majemuk Dan Konsentrasi Em-4 Terhadap Pertumbuhan Bibit Stek Tebu (Saccharum officinarum L.J. Fakultas Pertanian. Universitas Sebelas Maret. Surakarta.

Prasetyo, B.H. dan D.A. Suriadikarta. 2006. Karakteristik, Potensi dan Teknologi Pengelolaan Tanah Ultisol untuk Pengembangan Pertanian Lahan Kering di Indonesia. Jumal Litbang Pertanian. 25(2): 39-46.

Rosdianingsih, Dini. 2016. Budidaya Tebu (Saccharum officinarum L.) Lahan Kering $\quad D i \quad P \quad G$ Madukismo $P T$. Madubaru Yogyakarta Dengan Aspek Khusus Pemupukan Beberapa Kategori Tanaman Tebu Lahan Kering. Skripsi. Institut Pertanian Bogor. Bogor.

Sukmadajaja, D. dan A. Mulyana. 2011. Regenerasi Dan Pertumbuhan Beberapa Varietas Tebu (Saccharum officinarum L.) Secara In Vitro. Jumal AgroBiogen 7(2): 106-118.

Sutedjo, M. M. 2010. Pupuk dan Cara Pemupukan. Rineka Cipta. Jakarta.

Supriyadi, Nunik Eka Diana, dan Djumali. 2017. Pengaruh Pupuk Majemuk Berbentuk Granul Dan Briket Terhadap Pertumbuhan, Produktivitas, Dan Rendemen Tebu. Buletin Tanaman Tembakau, Serat \& Minyak Industri 9 (1) : 34-41. 